\title{
Genetics of the type I interferon pathway in systemic lupus erythematosus
}

\author{
Yogita Ghodke-Puranik ${ }^{1}$ and Timothy B Niewold ${ }^{1, *}$ \\ ${ }^{1}$ Division of Rheumatology, Department of Immunology, Mayo Clinic, 2001 st Street SW, \\ Guggenheim Building 3-42, Rochester, MN 55905, USA
}

\section{Abstract}

Genetic studies of systemic lupus erythematosus (SLE) have been successful, identifying numerous risk factors for human disease. While the list is not yet complete, it is clear that important immune system pathways are represented, one of which being type I interferon (IFN). Circulating type I IFN levels are high in SLE patients and this IFN pathway activation is heritable in families with SLE. We summarize our current understanding of the genetics of the type I IFN pathway in SLE, with an emphasis on studies that demonstrate an impact of the SLE-risk alleles upon type I IFN pathway activation in SLE patients. These studies illustrate that variations in type I IFN pathway genes represent a common genetic feature of SLE. By understanding the genetic regulation of type I IFN, we may be able to intervene in a more personalized fashion, based upon the molecular dysregulation present in a given individual.

\section{Keywords}

autoantibodies; autoimmune diseases; genetics; interferon; systemic lupus erythematosus

\begin{abstract}
Systemic lupus erythematosus (SLE) is a chronic systemic autoimmune disease involving multiple organs including the skin, musculoskeletal, renal and hematologic systems. SLE incidence is high in women compared with men (at a 9:1 ratio), particularly during reproductive years $[1,2]$. The production of circulating autoantibodies directed against dsDNA (anti-dsDNA) and small nuclear RNA-binding proteins (such as anti-Ro, anti-La, anti-Sm and anti-RNP) is a cardinal feature of SLE [3]. The pathogenesis of SLE is multifactorial and likely governed by a combination of genetic predispositions and environmental factors, resulting in an irreversible break in immunologic self-tolerance [4]. It is difficult to predict the spectrum of organ-system involvement and long-term outcomes in an individual patient, as the clinical manifestations of SLE are highly diverse.

Familial aggregation and monozygotic twin studies strongly support the idea that SLE has a genetic component. Familial aggregation studies demonstrated that siblings of SLE patients have greater relative risk for the disease, with a sibling risk ratio $(\lambda s)$ as high as 29 compared with the general population [5]. Similarly, a much higher concordance rate of SLE was observed among monozygotic twins (30\%) compared with dizygotic twins (3\%) [6,7]. In
\end{abstract}

\footnotetext{
(C) 2013 Future Medicine Ltd

*Author for correspondence: Tel.: +1 507284 8450, Fax: +1 507284 0564, niewold.timothy@ mayo.edu.

Financial \& competing interests disclosure

TB Niewold received research grants from the NIH (R01 AR060861, K08 AI083790 and AI071651). The authors have no other relevant affiliations or financial involvement with any organization or entity with a financial interest in or financial conflict with the subject matter or materials discussed in the manuscript apart from those disclosed.

No writing assistance was utilized in the production of this manuscript.
} 
families with multiple affected members, the disease occurrence does not typically follow classical Mendelian inheritance. However, in a few cases, SLE is associated with highly penetrant rare mutations, resulting in complete deficiencies in classical complement components and/or defective DNA degradation. Relatively rare, but complete deficiency of the early complement pathway genes, such as $C 1 Q, C 1 R / S, C 2, C 4 A$ and $C 4 B$ are associated with SLE [8-11]. Deficiencies of the classical complement component pathway are likely to affect SLE pathogenesis by reducing clearance of apoptotic cell debris and immune complexes (IC), resulting in increased self-antigen availability and increased IC-related Toll-like receptor (TLR) signaling [12]. The genes for complement components $C 2$ and $C 4$ are in linkage disequilibrium with MHC polymorphisms, and these genes are hypothesized to contribute independently to the risk of SLE [13]. Rare coding-change variants in TREXI, which encodes a DNA exonuclease, are also associated with SLE susceptibility [14], and a family has been described in which a recessive loss of DNASE1L3 resulted in SLE [15].

Initial studies exploring SLE genetics included targeted and genome-wide linkage analysis in multiplex families, as well as candidate gene association studies. The drawbacks of these studies included bias in candidate gene selection, based on functional relevance to disease pathogenesis, lack of dense marker sets, and inability to map genetic variants of small phenotypic effect size [16]. Despite these limitations, some risk loci, such as IRF5, were identified in these early studies [17]. More recently, genetic studies of SLE based on highdensity genome-wide association studies (GWAS) have been extremely successful. Since 2008, numerous GWAS have been performed in patients with SLE in various ethnic populations and currently more than 40 loci are definitively linked to SLE susceptibility in case-control genetic studies $[18,19]$. As predicted, the $H L A$ locus consistently provides the strongest evidence for association among the common genetic variants linked to SLE. Many non- $H L A$ loci are located within or near genes with functional relevance in the immune system, implicating the involvement of specific immune pathways. Case-control genetic studies in SLE have recently been reviewed [18,19], and a summary of SLE-associated loci and potential function of these genes is provided in Table 1. Remarkably, there is overrepresentation of a number of genes involved in type I interferon (IFN) signaling, production and response. In this review we will discuss recent advances in genetics of type I IFN in SLE pathogenesis.

\section{Role of type I IFN in SLE}

The biological role of type I IFN in the pathogenesis of human SLE has been an area of considerable interest [20-23]. High levels of type I IFN have been observed in serum of SLE patients [24]. Consistent with this observation, gene expression studies have shown that there is a dominant pattern of IFN-inducible gene expression signatures in peripheral blood mononuclear cells from patients with SLE [25,26]. The genes that are overexpressed in the peripheral blood cells of SLE patients are not necessarily the same genes that are implicated as genetic risk factors. Instead, the pattern of IFN-induced gene expression in peripheral blood strongly supports the idea that the type I IFN receptor is being ligated in these cells. Type I IFNs include IFN- $\alpha$ and IFN- $\beta$; both of these cytokines signal through the same type I IFN receptor and play a vital role in viral defense. IFN-a signaling results in wide range of effects on the immune system, including the activation of dendritic cells and other antigenpresenting cells, as well as increased expression of MHC class I and II molecules, leading to increased antigen presentation [27]. Thus, IFN-a is a critical mediator which bridges the innate and adaptive immune systems, supporting its importance in setting thresholds for selfreactivity and autoimmunity. Serum IFN- $a$ is elevated in many SLE patients and elevations frequently correlate with disease activity [24,25,28-30]. A subset of patients administered recombinant IFN-a as a therapy for chronic viral hepatitis and malignancy, developed a lupus-like syndrome that was reversible when IFN-a therapy is discontinued $[31,32]$. This 
experience provides some proof of principle that IFN-a can break tolerance in humans, and highlights its causative role in SLE etiology and pathogenesis [33]. Additionally, the effect of age and sex on serum IFN-a activity has been evaluated in families with lupus [34]. It was observed that serum IFN- $a$ activity is higher in younger individuals in the SLE family cohorts, and this trend is accentuated in affected individuals, suggesting that the age-related pattern of IFN-a activity may contribute to the increased incidence of SLE in early adulthood. Interestingly, each gender had similar age-related patterns of IFN-a activity [34].

\section{High serum IFN- $\alpha$ : a heritable risk factor for SLE}

Abnormally high levels of IFN-a are present in $20 \%$ of healthy first-degree relatives of SLE patients as compared with 5\% of healthy unrelated subjects [35], suggesting that high serum IFN-a is an inherited risk factor for SLE. Twins tended to be concordant for high or low IFN-a. Spouses of SLE patients did not have high serum IFN-a, supporting the concept that genetic, and not environmental factors, are driving familial clustering [36]. A number of genetic variants have now been associated with increased IFN-a in SLE [20-22], highlighting some of the genetic architecture of this SLE-associated trait and supporting the concept of heritability. The high IFN-a trait is shared across SLE patients of all ancestral backgrounds [37], although the particular genetic variants responsible for this SLEassociated trait sometimes differ between ancestral backgrounds [36,38-41].

\section{Genetic variants in IFN \& IFN-related pathways are associated with SLE risk}

Over the past 5 years, there has been significant progress in the identification of type I IFN pathway genes that associate with SLE. IFN-related genetic variants playing an important role in SLE pathogenesis are discussed in detail below.

\section{IRF5}

Certain lupus-associated genetic variations have been shown to increase IFN-a levels or response to IFN-a signaling. IRF5 is one of a family of nine IFN regulatory factors, three of which have been genetically associated with SLE [42]. IRF5 is particularly relevant when considering the genetic architecture of type I IFN production in SLE because it can induce transcription of IFN-a mRNA [43]. IRF5 itself is activated by IFN-a signaling, producing a potential positive feedback loop. In addition to type I IFN [44], IRF5 plays a role in upregulating expression of IL-6, IL-12b, IL-17, IL-23, TNF- $a$, IFN- $\beta$-IP-10, MCP1 and RANTES $[45,46]$ and hence has been called the 'master regulator of proinflammatory cytokines' $[42,47]$. IRF5 has been confirmed as a risk locus for SLE in several different ancestral backgrounds [48-52], and a number of functional genetic variants have been identified. One well-studied single nucleotide polymorphism (SNP), rs2004640, creates an alternate splice site (exon 1B) in the untranslated first exon [53], and this locus has subsequently been replicated in individuals of European, African and Asian ancestry [30,49,50,53-58]. Other functional elements include a 30-bp insertion/deletion sequence in exon 6 [31], a five base pair insertion-deletion proximal to the 5' UTR [59] and rs10954213, which creates an alternate polyadenylation site, resulting in shorter and more stable mRNA [54]. Haplotypes generated from combination of these variants are associated with varying degrees of SLE risk, although linkage disequilibrium makes it difficult to unravel the functional impact of specific variants. Since IRF5 activates IFN-a production, presumably the SLE-risk associated variants may result in excess IFN-a production. Niewold et al. [30,58] studied this question in SLE patients, and found that the risk haplo-type of IRF5 predisposes to greater serum IFN-a, supporting the idea that the risk haplotype is a gain-offunction variant. It was observed that the effect of IRF5 genotype on serum IFN-a levels was driven by the presence of anti-dsDNA and anti-RNA-binding protein autoantibodies, supporting a 'gene plus autoantibody equals high IFN-a' pattern of association [58]. This 
suggests that these autoantibodies may provide chronic stimulation of the endosomal TLR pathway of IFN-a generation, and that this chronic stimulation combined with gain-offunction polymorphisms in IRF5 results in dysregulation of the pathway SLE patients in vivo [21].

It is possible that IRF5 haplotypes are associated with autoantibodies only because these antibodies stimulate the TLR receptors and activate the particular IRF5 variants to result in type I IFN generation, which then predisposes to lupus. It is also possible that IRF5 variants could directly predispose the autoantibody formation, potentially via a role for IRF5 in TLR signaling in B cells, and these human cross-sectional analyses do not rule out this possibility. In fact, in a murine SLE model, knockout of IRF5 results in a significant decrease in autoantibody formation [60]. Cherian et al. [61] studied IRF5 polymorphisms in a unique population of autoantibody-positive asymptomatic individuals to address this question directly - does IRF5 influence the formation of these autoantibodies in humans outside the context of SLE? They found that IRF5 haplotypes were strongly associated with anti-Ro antibody formation, supporting the idea of a feed-forward loop, in which IRF5 facilitates autoantibody formation, and then the autoantibodies trigger increased type I IFN production in the setting of the same gain-of-function variations [42].

\section{IRF7}

IRF7 can also stimulate induction of IFN-a RNA [62].

IRF7 is a transcription factor found in plasmacytoid dendritic cells (pDCs), which is critical for TLR signaling leading to type I IFN production [63]. It interacts with the TLR adaptors MyD88 and TRIF, and heterodimerizes with IRF5 [64]. IRF7 has been highlighted by the association of the IRF7/KIAAI542 locus with lupus in recent studies $[65,66]$. The top risk variant in this region is the intronic rs $4963128^{*} \mathrm{C}$ SNP located in PHRF1, a gene directly upstream of IRF7; the risk haplotype includes the entire IRF7 gene [65]. It has been observed that a nonsynonymous SNP, rs1131665 (412Q) in IRF7, confers elevated activation of IRF7 and predisposes to the development of SLE in multiple ethnic groups [67]. Salloum et al. [40] examined the relationship between IRF7/PHRFI locus, presence of autoantibodies and presence of serum IFN- $a$. Their findings indicated that IRF7 variants in combination with SLE-associated autoantibodies result in higher serum levels of IFN-a. IRF5 and IRF7 are activated by signaling through the endosomal TLRs 7,8 and 9 . Interestingly, when IRF5 and IRF7 risk genotypes were examined together, an additive effect was observed on serum IFN-a.

\section{IRF8}

A third member of the IFN regulatory factor family, $I R F 8$, was reported as an associated risk factor for SLE in a recent large-scale multiracial GWAS replication [68]. Additionally, it has been demonstrated that a functional polymorphism in the $3^{\prime}$ UTR of $S P I 1$, is known to regulate expression of IRF2, IRF4 and IRF8 [69-71]. Also within the IRF8 locus, a different variant has been associated with risk of multiple sclerosis (MS) [72], underscoring the significance of this region to autoimmune disease susceptibility. It is remarkable that different genetic variations in the same $I R F$ gene are associated with two autoimmune syndromes that demonstrate an opposite relationship with type I IFN (causal in SLE, and therapeutic in MS). To explore this relationship of IRF8 with type I IFN in SLE and MS, Chrabot et al. [73] investigated the association of IRF8 alleles with type I IFN levels and serologic profiles in SLE and MS. The study reported that the MS-associated rs17445836G allele was associated with antidsDNA autoantibodies in SLE patients. This allele was also associated with increased IRF8 expression in SLE patient B cells, supporting its role in humoral tolerance. The same allele was associated with decreased serum IFN activity and 
decreased type I IFN-induced gene expression in SLE patients. In secondary progressive MS patients, rs17445836G was also associated with decreased serum type I IFN. Thus, carriage of the IRF8 rs $17445836 \mathrm{G}$ in human autoimmune disease patients is characterized by lowtype I IFN levels and autoantibody formation. These data may be relevant to pharmacogenetics as type I IFN is modulated in SLE and MS. The discovery of genetic associations between IRF 8 variants in both SLE and multiple sclerosis are recent, and further fine-mapping and sequencing of this region will likely be required to understand the functional genetic variations underlying these associations.

\section{STAT4}

STAT4 encodes the STAT4 and represents one of six primary members of the STAT family, all of which play important roles in cytokine signaling. It is involved in proliferation, differentiation and apoptosis. The STAT4 gene can be activated and phosphorylated upon ligation of the type I IFN receptor by IFN-a [74], and subsequently induce downstream transcription of IFN-a-induced genes. The minor T allele of rs7574865, in the third intron of STAT4 has been associated with risk of SLE in individuals of European ancestry [75], and this SNP has been associated with risk of rheumatoid arthritis in individuals of European and Asian ancestry [75,76]. Kariuki et al. [77] demonstrated that the risk variant of STAT4 (T allele; rs7574865) was associated with increased sensitivity to IFN-a signaling. This STAT4-SLE association was further replicated in multiple GWAS in European or Asian ancestry [65,78-80]. The SNP rs7574865 is also associated with a more severe SLE phenotype, which is characterized by disease onset at a younger age ( $<30$ years), a high frequency of nephritis and the presence of anti-dsDNA antibodies [81-83]. An association between rs7574865 and anti-dsDNA-positive autoantibody production in SLE ( $\mathrm{p}=2 \times$ $10^{-20}$ ) has been confirmed in a GWAS by Chung et al. [84]. A recent meta-analysis also supports the association between the STAT4 rs7574865 polymorphism with SLE and the presence of anti-dsDNA antibodies in SLE patients [85].

\section{PTPN22}

PTPN22 encodes PTPN22, a lymphoid-specific phosphatase known to inhibit T-cell activation [86]. A nonsynonymous SNP rs2476601 (Arg-620Trp) C1858T in PTPN22 results in decreased $\mathrm{T}$ - and $\mathrm{B}$-cell responsiveness, as well as deregulated cytokine production in lymphocytes in vitro $[87,88]$. This SNP has been associated with risk of SLE, as well as multiple other autoimmune diseases including autoimmune thyroid disease, juvenile idiopathic arthritis, rheumatoid arthritis, and Type I diabetes [89]. Interestingly, PTPN22 risk alleles are not a common feature of all autoimmune diseases and, in fact, the $1858 \mathrm{~T}$ multiple autoimmune disease risk allele is actually associated with protection against Crohn's disease [90]. GWAS of SLE have confirmed the association between rs2476601 and SLE in European populations [65,78] but a similar association has not been observed in the Asian GWAS studies done to date [79,91]. This difference may be due to the decreased frequency of the risk allele in non-European ancestry populations. There is even a large northern versus southern Europe allelic gradient, and a two- to three-fold decrease in the allele frequency in southern Europe has impeded statistical power in this population [92] A recent meta-analysis demonstrated that the rs2476601 SNP was associated with SLE susceptibility in different ancestral groups, and that its prevalence varies widely by ancestry [93]. PTPN22 has also been associated with anti-dsDNA autoantibody production in SLE [84].

Studies have shown that the Arg620Trp change increases the intrinsic lymphoid-specific phosphatase activity of $P T P N 22$, by reducing the threshold for T-cell receptor signaling and promoting autoimmunity [94]. Supporting this idea, a PTPN22 variant that reduces the phosphatase activity of PTPN22 (Arg263Gln in the catalytic domain) and thus increases the 
threshold for T-cell receptor signaling has been associated with protection against SLE in European populations [95]. It has also been suggested that the PTPN22 allele associated with autoimmune disease impairs the removal of autoreactive $\mathrm{B}$ cells, supporting both $\mathrm{T}$ and B cell effects of this allele [96]. A relationship between PTPN22 and the type I IFN pathway has been proposed on the basis of elevated serum IFN- $a$ and decreased TNF-a levels in SLE patients carrying the rs 2476601 risk allele [97,98].

OPN

OPN or SPP1 is a secreted extracellular matrix cell adhesion glycoprotein expressed in bone, damaged renal tissues and T cells. OPN has been implicated in the development of murine lupus and is overexpressed in humans with SLE [99,100]. OPN has diverse immunological functions such as macrophage chemotaxis, T-helper type 1 polarization and B-cell activation, supporting its role in SLE pathogenesis [101]. OPN interacts with the MyD88 adaptor protein downstream of TLR ligation, and is a key molecule for IFN-a production in pDCs [102]. High levels of OPN have been documented in biopsies of inflamed tissues in SLE and other autoimmune diseases [103,104]. In addition, studies have shown that an increased plasma OPN level is correlated with increased disease activity and organ damage in SLE patients $[105,106]$.

Genetic variants of the $O P N$ gene have been associated with SLE susceptibility $[100,107,108]$. Presence of the lupus risk allele (rs9138C) was associated with high IFN levels in males and young-onset female lupus patients [109]. Additionally, a number of studies have linked $O P N$ alleles to clinical manifestations in SLE. A study of EuropeanAmerican ancestry patients demonstrated an association between lymphadenopathy and rs7687316 in the promoter region [108]. Another study of 81 SLE patients of EuropeanAmerican ancestry demonstrated an association between a synonymous change in exon 7 with avascular necrosis and renal insufficiency [100]. A third study examining clinical subphenotypes of SLE in relation to SLE risk alleles of the $O P N$ gene in multiethnic cohort revealed that the risk allele rs9138C in the $3^{\prime}$ UTR was associated with photosensitivity in lupus patients across all ancestral backgrounds. Additionally, the promoter variant rs $11730582 \mathrm{C}$ demonstrated suggestive evidence for association with two hematologic traits: thrombocytopenia and hemolytic anemia [110]. These clinical associations with SNPs in the promoter and 3' UTRs are in accordance with previously reported SLE-susceptibility SNPs in $O P N$, and suggest potential roles for these variants in antibody-mediated cytopenias and skin inflammation in SLE.

\section{IFIH1}

IFIH1 (also known as MDA5) is a DEAD-box helicase that recognizes viral RNA and mediates transcription of type I IFN and IFN-induced genes when activated [111]. IFIH1 is localized in the cytoplasm, and shares significant similarities with $R I G-I$, another cytoplasmic RNA sensor [111]. Genetic variants of IFIHI have been associated with Type I diabetes [112], autoimmune thyroid disease [113], psoriasis [114] and, more recently, with SLE $[65,78,115]$. A common coding-change variant in IFIHI (rs1990760, A946T) has been associated with these autoimmune conditions. This coding-change variant is not predicted to induce a damaging change to local protein folding by informatics algorithms, but instead has been associated with increased IFIH1 expression. Thus, the A946T variant is likely to be a gain-of-function in nature [116], although this finding has not been uniformly replicated [117]. Additionally, rare loss-of-function variations in IFIHI (nonsense mutations, among others) have been shown to be protective against Type I diabetes [118]. Taken together, these data propose that increased expression or gain-of-function in IFIH1 predisposes to human autoimmunity. 
Based on the importance of this protein in type I IFN responses and the pathogenic importance of IFN-a in human SLE, Robinson et al. investigated the impact of the IFIHI rs1990760 polymorphism on the IFN-a pathway in SLE patients in vivo. They reported the risk allele was associated with dsDNA, and modulated IFN-a-induced gene expression in peripheral blood cells in anti-dsDNA positive SLE patients [119]. A study in transgenic murine models revealed that IFIH1 overexpression, when combined with a SLE-susceptible genetic background ( $F C G R 2 B$ deficiency), led to chronic type I IFN pathway activation that triggered autoimmunity manifested by accelerated production of switched autoantibodies, increased glomerulonephritis and early lethality [120].

\section{TYK2}

TYK2 is a member of the JAK family of nonreceptor tyrosine kinases that play a vital role in initiating signaling cascades of a large number of cytokine receptors [121]. In the type I IFN pathway, TYK2 is stably associated to the IFN-a receptor (IFNAR1/2) complex, along with JAK1. TYK2 is phosphorylated following receptor ligation, and initiates a JAK/STAT signaling cascade leading to the transcription of IFN-induced genes [122-124]. Along with the type I IFN pathway, TYK2 is also important in the response to IL-12 and IL-23, as well as several members of the IL-6 and IL-10 receptor families [125].

The SNPs in TYK2 loci have been associated with SLE [17,66,126-129]. In a Scandinavian study, a strong association signal was observed for rs 2304256 in all patients and for rs12720356 in the Swedish patients only [17]. The rs2304256 SNP is located in exon 8 results in Val362Phe substitution in the JH4 region of TYK2. This region is essential for the interaction of TYK2 with IFNAR1 [124]. There is another common missense variant in TYK2 (rs12720356, Ile-684Ser), located in the pseudo kinase region JH2 [17]. When studied in isolation neither of these SNP showed an association in the UK study; however, rs2304256 was reported to lie within an identified core associated region of $2.8 \mathrm{~kb}$ [126]. In the UK data, rs 12720270 showed the strongest association, with the $\mathrm{G}$ allele being over transmitted in SLE families. This variant is located close to an intron/exon boundary, suggesting a potential role for this allele in aberrant splicing events [126]. Hellquist et al. replicated the association between the C allele of rs2304256 and risk for SLE [127]; however, the International Consortium on the Genetics of Systemic Lupus Erythematosus GWAS failed to replicate this association [65]. Hellquist et al. also reported that the G allele of rs12720270 was found significantly more often in SLE cases than in controls. The rs12720356 SNP failed to show association to SLE in the Finnish population when analyzed individually; however, in agreement with the UK study, two TYK2 haplotypes (includes all three markers) showed evidence for association with SLE [127]. It is possible that future fine-mapping and replication studies will clarify the association between TYK2 and SLE.

\section{Conclusion}

This review summarizes important recent advances in our understanding of the genetics of the type I IFN pathway in human SLE. SLE is highly heritable, polygenic in nature and likely results from the synergistic effect of different genetic loci that are impacting upon different immune system phenotypes in concert. Advances in genotyping technology and the assembly of large patient sample collections have helped us to explore common gene variants in SLE pathogenesis, and current studies are aggressively validating these associations across different ancestral backgrounds. With the increased use of next generation sequencing, we are also identifying additional rare variations that are associated with SLE. Our next major frontier is in understanding the molecular and immunologic significance of the genetic variations that are associated with SLE. This review outlines 
some very promising work that has transpired in the field of type I IFN pathway genetic variants and, of course, there are still many open questions.

\section{Future perspective}

In next 5-10 years, remarkable advances in next-generation sequencing technologies and bioinformatics will continue to aid us in identifying additional risk loci, novel rare variants, copy number variations and functional variants in multiple ancestral backgrounds that might account for more of the inherited liability of SLE. In addition, epigenetic studies will also help to show us how expression of the genetic sequence is modified in different situations and different cell types. We feel that functional studies of causal allelic variants will provide key advances in our ability to translate genetic associations into new diagnostic applications and therapeutic targets for SLE. Ideally, the field is working toward understanding the genetic regulation of immune system pathways that will allow prediction of disease onset, disease manifestations and severity, and also response/nonresponse to therapeutic intervention. In particular, studies such as those addressing type I IFN may be important to therapeutics, as targeting cytokines has been a successful approach in many autoimmune diseases, and type I IFN inhibitors are currently in clinical trials in SLE.

\section{References}

1. Lopez P, Mozo L, Gutierrez C, Suarez A. Epidemiology of systemic lupus erythematosus in a northern Spanish population: gender and age influence on immunological features. Lupus. 2003; 12(11):860-865. [PubMed: 14667105]

2. Weckerle CE, Niewold TB. The unexplained female predominance of systemic lupus erythematosus: clues from genetic and cytokine studies. Clin Rev Allergy Immunol. 2011; 40(1): 42-49. [PubMed: 20063186]

3. von Muhlen CA, Tan EM. Autoantibodies in the diagnosis of systemic rheumatic diseases. Semin Arthritis Rheum. 1995; 24(5):323-358. [PubMed: 7604300]

4. Harley JB, Kelly JA, Kaufman KM. Unraveling the genetics of systemic lupus erythematosus. Springer Semin Immunopathol. 2006; 28(2):119-130. [PubMed: 17021721]

5. Alarcon-Segovia D, Alarcon-Riquelme ME, Cardiel MH, et al. Familial aggregation of systemic lupus erythematosus, rheumatoid arthritis, and other autoimmune diseases in 1,177 lupus patients from the GLADEL cohort. Arthritis Rheum. 2005; 52(4):1138-1147. [PubMed: 15818688]

6. Deapen D, Escalante A, Weinrib L, et al. A revised estimate of twin concordance in systemic lupus erythematosus. Arthritis Rheum. 1992; 35(3):311-318. [PubMed: 1536669]

7. Block SR, Winfield JB, Lockshin MD, D'Angelo WA, Christian CL. Studies of twins with systemic lupus erythematosus. A review of the literature and presentation of 12 additional sets. Am J Med. 1975; 59(4):533-552. [PubMed: 1101680]

8. Pettigrew HD, Teuber SS, Gershwin ME. Clinical significance of complement deficiencies. Ann NY Acad Sci. 2009; 1173:108-123. [PubMed: 19758139]

9. Slingsby JH, Norsworthy P, Pearce G, et al. Homozygous hereditary C1q deficiency and systemic lupus erythematosus. A new family and the molecular basis of $\mathrm{C} 1 \mathrm{q}$ deficiency in three families. Arthritis Rheum. 1996; 39(4):663-670. [PubMed: 8630118]

10. Provost TT, Arnett FC, Reichlin M. Homozygous C2 deficiency, lupus erythematosus, and anti-Ro (SSA) antibodies. Arthritis Rheum. 1983; 26(10):1279-1282. [PubMed: 6605148]

11. Fielder AH, Walport MJ, Batchelor JR, et al. Family study of the major histocompatibility complex in patients with systemic lupus erythematosus: importance of null alleles of C4A and C4B in determining disease susceptibility. Br Med J (Clin Res Ed). 1983; 286(6363):425-428.

12. Truedsson L, Bengtsson AA, Sturfelt G. Complement deficiencies and systemic lupus erythematosus. Autoimmunity. 2007; 40(8):560-566. [PubMed: 18075790]

13. Davies EJ, Steers G, Ollier WE, et al. Relative contributions of $H L A-D Q A$ and complement C4A loci in determining susceptibility to systemic lupus erythematosus. Br J Rheumatol. 1995; 34(3): 221-225. [PubMed: 7728395] 
14. Lee-Kirsch MA, Gong M, Chowdhury D, et al. Mutations in the gene encoding the $3^{\prime}-5^{\prime}$ DNA exonuclease TREX1 are associated with systemic lupus erythematosus. Nat Genet. 2007; 39(9): 1065-1067. [PubMed: 17660818]

15. Al-Mayouf SM, Sunker A, Abdwani R, et al. Loss-of-function variant in DNASE1L3 causes a familial form of systemic lupus erythematosus. Nat Genet. 2011; 43(12):1186-1188. [PubMed: 22019780]

16. Deng Y, Tsao BP. Genetic susceptibility to systemic lupus erythematosus in the genomic era. Nat Rev Rheumatol. 2010; 6(12):683-692. [PubMed: 21060334]

17. Sigurdsson S, Nordmark G, Goring HH, et al. Polymorphisms in the tyrosine kinase 2 and interferon regulatory factor 5 genes are associated with systemic lupus erythematosus. Am J Hum Genet. 2005; 76(3):528-537. [PubMed: 15657875]

18. Rullo OJ, Tsao BP. Recent insights into the genetic basis of systemic lupus erythematosus. Ann Rheum Dis. 2013; 72(Suppl 2):ii56-ii61. [PubMed: 23253915]

19. Cui Y, Sheng Y, Zhang X. Genetic susceptibility to SLE: recent progress from GWAS. J Autoimmun. 2013; 41:25-33. [PubMed: 23395425]

20. Niewold TB. Interferon alpha as a primary pathogenic factor in human lupus. J Interferon Cytokine Res. 2011; 31(12):887-892. [PubMed: 21923413]

21. Niewold TB, Clark DN, Salloum R, Poole BD. Interferon alpha in systemic lupus erythematosus. J Biomed Biotechnol. 2010; 2010:948364. [PubMed: 20652065]

22. Bronson PG, Chaivorapol C, Ortmann W, Behrens TW, Graham RR. The genetics of type I interferon in systemic lupus erythematosus. Curr Opin Immunol. 2012; 24(5):530-537. [PubMed: 22889593]

23. Connolly JJ, Hakonarson H. Role of cytokines in systemic lupus erythematosus: recent progress from GWAS and sequencing. J Biomed Biotechnol. 2012; 2012:798924. [PubMed: 22654485]

24. Hooks JJ, Moutsopoulos HM, Geis SA, Stahl NI, Decker JL, Notkins AL. Immune interferon in the circulation of patients with autoimmune disease. N Engl J Med. 1979; 301(1):5-8. [PubMed: 449915]

25. Baechler EC, Batliwalla FM, Karypis G, et al. Interferon-inducible gene expression signature in peripheral blood cells of patients with severe lupus. Proc Natl Acad Sci USA. 2003; 100(5):2610 2615. [PubMed: 12604793]

26. Crow MK, Wohlgemuth J. Microarray analysis of gene expression in lupus. Arthritis Res Ther. 2003; 5(6):279-287. [PubMed: 14680503]

27. Takaoka A, Yanai H. Interferon signalling network in innate defence. Cell Microbiol. 2006; 8(6): 907-922. [PubMed: 16681834]

28. Kirou KA, Lee C, George S, Louca K, Peterson MG, Crow MK. Activation of the interferon-alpha pathway identifies a subgroup of systemic lupus erythematosus patients with distinct serologic features and active disease. Arthritis Rheum. 2005; 52(5):1491-1503. [PubMed: 15880830]

29. Ytterberg SR, Schnitzer TJ. Serum interferon levels in patients with systemic lupus erythematosus. Arthritis Rheum. 1982; 25(4):401-406. [PubMed: 6176248]

30. Niewold TB, Kelly JA, Flesch MH, Espinoza LR, Harley JB, Crow MK. Association of the IRF5 risk haplotype with high serum interferon-alpha activity in systemic lupus erythematosus patients. Arthritis Rheum. 2008; 58(8):2481-2487. [PubMed: 18668568]

31. Ronnblom LE, Alm GV, Oberg KE. Possible induction of systemic lupus erythematosus by interferon-alpha treatment in a patient with a malignant carcinoid tumour. J Intern Med. 1990; 227(3):207-210. [PubMed: 1690258]

32. Niewold TB, Swedler WI. Systemic lupus erythematosus arising during interferon-alpha therapy for cryoglobulinemic vasculitis associated with hepatitis C. Clin Rheumatol. 2005; 24(2):178-181. [PubMed: 15565395]

33. Niewold TB. Interferon alpha-induced lupus: proof of principle. J Clin Rheumatol. 2008; 14(3): 131-132. [PubMed: 18525429]

34. Niewold TB, Adler JE, Glenn SB, Lehman TJ, Harley JB, Crow MK. Age- and sex-related patterns of serum interferon-alpha activity in lupus families. Arthritis Rheum. 2008; 58(7):2113-2119. [PubMed: 18576315] 
35. Niewold TB, Hua J, Lehman TJ, Harley JB, Crow MK. High serum IFN-alpha activity is a heritable risk factor for systemic lupus erythematosus. Genes Immun. 2007; 8(6):492-502. [PubMed: 17581626]

36. Kariuki SN, Franek BS, Kumar AA, et al. Trait-stratified genome-wide association study identifies novel and diverse genetic associations with serologic and cytokine phenotypes in systemic lupus erythematosus. Arthritis Res Ther. 2010; 12(4):R151. [PubMed: 20659327]

37. Weckerle CE, Franek BS, Kelly JA, et al. Network analysis of associations between serum interferon-alpha activity, autoantibodies, and clinical features in systemic lupus erythematosus. Arthritis Rheum. 2011; 63(4):1044-1053. [PubMed: 21162028]

38. Kariuki SN, Franek BS, Mikolaitis RA, et al. Promoter variant of PIK3C3 is associated with autoimmunity against Ro and Sm epitopes in African-American lupus patients. J Biomed Biotechnol. 2010; 2010:826434. [PubMed: 20671926]

39. Lodolce JP, Kolodziej LE, Rhee L, et al. African-derived genetic polymorphisms in TNFAIP3 mediate risk for autoimmunity. J Immunol. 2010; 184(12):7001-7009. [PubMed: 20483768]

40. Salloum R, Franek BS, Kariuki SN, et al. Genetic variation at the IRF7/PHRF1 locus is associated with autoantibody profile and serum interferon-alpha activity in lupus patients. Arthritis Rheum. 2010; 62(2):553-561. [PubMed: 20112359]

41. Pothlichet J, Niewold TB, Vitour D, Solhonne B, Crow MK, Si-Tahar M. A loss-of-function variant of the antiviral molecule MAVS is associated with a subset of systemic lupus patients. EMBO Mol Med. 2011; 3(3):142-152. [PubMed: 21268286]

42. Cham CM, Ko K, Niewold TB. Interferon regulatory factor 5 in the pathogenesis of systemic lupus erythematosus. Clin Dev Immunol. 2012; 2012:780436. [PubMed: 23251221]

43. Barnes BJ, Moore PA, Pitha PM. Virus-specific activation of a novel interferon regulatory factor, IRF-5, results in the induction of distinct interferon alpha genes. J Biol Chem. 2001; 276(26): 23382-23390. [PubMed: 11303025]

44. Kozyrev SV, Alarcon-Riquelme ME. The genetics and biology of Irf5-mediated signaling in lupus. Autoimmunity. 2007; 40(8):591-601. [PubMed: 18075793]

45. Sweeney SE. Targeting interferon regulatory factors to inhibit activation of the type I IFN response: implications for treatment of autoimmune disorders. Cell Immunol. 2011; 271(2):342349. [PubMed: 21872224]

46. Krausgruber T, Blazek K, Smallie T, et al. IRF5 promotes inflammatory macrophage polarization and TH1-TH17 responses. Nat Immunol. 2011; 12(3):231-238. [PubMed: 21240265]

47. Santana-de Anda K, Gomez-Martin D, Diaz-Zamudio M, Alcocer-Varela J. Interferon regulatory factors: beyond the antiviral response and their link to the development of autoimmune pathology. Autoimmun Rev. 2011; 11(2):98-103. [PubMed: 21872684]

48. Lee YH, Song GG. Association between the rs2004640 functional polymorphism of interferon regulatory factor 5 and systemic lupus erythematosus: a meta-analysis. Rheumatol Int. 2009; 29(10):1137-1142. [PubMed: 19043711]

49. Kawasaki A, Kyogoku C, Ohashi J, et al. Association of IRF5 polymorphisms with systemic lupus erythematosus in a Japanese population: support for a crucial role of intron 1 polymorphisms. Arthritis Rheum. 2008; 58(3):826-834. [PubMed: 18311811]

50. Kelly JA, Kelley JM, Kaufman KM, et al. Interferon regulatory factor-5 is genetically associated with systemic lupus erythematosus in African Americans. Genes Immun. 2008; 9(3):187-194. [PubMed: 18288123]

51. Reddy MV, Velazquez-Cruz R, Baca V, et al. Genetic association of IRF5 with SLE in Mexicans: higher frequency of the risk haplotype and its homozygozity than Europeans. Hum Genet. 2007; 121(6):721-727. [PubMed: 17476532]

52. Shimane K, Kochi Y, Yamada R, et al. A single nucleotide polymorphism in the IRF5 promoter region is associated with susceptibility to rheumatoid arthritis in the Japanese population. Ann Rheum Dis. 2009; 68(3):377-383. [PubMed: 18408250]

53. Graham RR, Kozyrev SV, Baechler EC, et al. A common haplotype of interferon regulatory factor 5 (IRF5) regulates splicing and expression and is associated with increased risk of systemic lupus erythematosus. Nat Genet. 2006; 38(5):550-555. [PubMed: 16642019] 
54. Graham RR, Kyogoku C, Sigurdsson S, et al. Three functional variants of IFN regulatory factor 5 (IRF5) define risk and protective haplotypes for human lupus. Proc Natl Acad Sci USA. 2007; 104(16):6758-6763. [PubMed: 17412832]

55. Demirci FY, Manzi S, Ramsey-Goldman R, et al. Association of a common interferon regulatory factor 5 (IRF5) variant with increased risk of systemic lupus erythematosus (SLE). Ann Hum Genet. 2007; 71(Pt 3):308-311. [PubMed: 17166181]

56. Shin HD, Sung YK, Choi CB, Lee SO, Lee HW, Bae SC. Replication of the genetic effects of IFN regulatory factor 5 (IRF5) on systemic lupus erythematosus in a Korean population. Arthritis Res Ther. 2007; 9(2):R32. [PubMed: 17389033]

57. Siu HO, Yang W, Lau CS, et al. Association of a haplotype of IRF5 gene with systemic lupus erythematosus in Chinese. J Rheumatol. 2008; 35(2):360-362. [PubMed: 18260169]

58. Niewold TB, Kelly JA, Kariuki SN, et al. IRF5 haplotypes demonstrate diverse serological associations which predict serum interferon alpha activity and explain the majority of the genetic association with systemic lupus erythematosus. Ann Rheum Dis. 2012; 71(3):463-468. [PubMed: 22088620]

59. Sigurdsson S, Goring HH, Kristjansdottir G, et al. Comprehensive evaluation of the genetic variants of interferon regulatory factor 5 (IRF5) reveals a novel 5 bp length polymorphism as strong risk factor for systemic lupus erythematosus. Hum Mol Genet. 2008; 17(6):872-881. [PubMed: 18063667]

60. Richez C, Yasuda K, Bonegio RG, et al. IFN regulatory factor 5 is required for disease development in the FcgammaRIIB ${ }^{-/}$Yaa and FcgammaRIIB ${ }^{-/-}$mouse models of systemic lupus erythematosus. J Immunol. 2010; 184(2):796-806. [PubMed: 20007534]

61. Cherian TS, Kariuki SN, Franek BS, Buyon JP, Clancy RM, Niewold TB. Brief report: IRF5 systemic lupus erythematosus risk haplotype is associated with asymptomatic serologic autoimmunity and progression to clinical autoimmunity in mothers of children with neonatal lupus. Arthritis Rheum. 2012; 64(10):3383-3387. [PubMed: 22674082]

62. Zhang L, Pagano JS. Structure and function of IRF-7. J Interferon Cytokine Res. 2002; 22(1):95101. [PubMed: 11846980]

63. Flesher DL, Sun X, Behrens TW, Graham RR, Criswell LA. Recent advances in the genetics of systemic lupus erythematosus. Expert Rev Clin Immunol. 2010; 6(3):461-479. [PubMed: 20441431]

64. Kawai T, Sato S, Ishii KJ, et al. Interferon-alpha induction through Toll-like receptors involves a direct interaction of IRF7 with MyD88 and TRAF6. Nat Immunol. 2004; 5(10):1061-1068. [PubMed: 15361868]

65. Harley JB, Alarcon-Riquelme ME, Criswell LA, et al. Genome-wide association scan in women with systemic lupus erythematosus identifies susceptibility variants in ITGAM, PXK, KIAA1542 and other loci. Nat Genet. 2008; 40(2):204-210. [PubMed: 18204446]

66. Suarez-Gestal M, Calaza M, Endreffy E, et al. Replication of recently identified systemic lupus erythematosus genetic associations: a case-control study. Arthritis Res Ther. 2009; 11(3):R69. [PubMed: 19442287]

67. Fu Q, Zhao J, Qian X, et al. Association of a functional IRF7 variant with systemic lupus erythematosus. Arthritis Rheum. 2011; 63(3):749-754. [PubMed: 21360504]

68. Lessard CJ, Adrianto I, Ice JA, et al. Identification of IRF8, TMEM39A, and IKZF3-ZPBP2 as susceptibility loci for systemic lupus erythematosus in a large-scale multiracial replication study. Am J Hum Genet. 2012; 90(4):648-660. [PubMed: 22464253]

69. Hikami K, Kawasaki A, Ito I, et al. Association of a functional polymorphism in the $3^{\prime}$ untranslated region of SPII with systemic lupus erythematosus. Arthritis Rheum. 2011; 63(3): 755-763. [PubMed: 21360505]

70. Yee AA, Yin P, Siderovski DP, Mak TW, Litchfield DW, Arrowsmith CH. Cooperative interaction between the DNA-binding domains of PU. 1 and IRF4. J Mol Biol. 1998; 279(5):1075-1083. [PubMed: 9642085]

71. Huang W, Horvath E, Eklund EA. PU 1, interferon regulatory factor (IRF) 2, and the interferon consensus sequence-binding protein (ICSBP/IRF8) cooperate to activate NF1 transcription in differentiating myeloid cells. J Biol Chem. 2007; 282(9):6629-6643. [PubMed: 17200120] 
72. De Jager PL, Jia X, Wang J, et al. Meta-analysis of genome scans and replication identify CD6, IRF8 and TNFRSF1A as new multiple sclerosis susceptibility loci. Nat Genet. 2009; 41(7):776782. [PubMed: 19525953]

73. Chrabot BS, Kariuki SN, Zervou MI, et al. Genetic variation near IRF8 is associated with serologic and cytokine profiles in systemic lupus erythematosus and multiple sclerosis. Genes Immun. 2013 (Epub ahead of print). 10.1038/gene.2013.42

74. Tyler DR, Persky ME, Matthews LA, Chan S, Farrar JD. Pre-assembly of STAT4 with the human IFN-alpha/beta receptor-2 subunit is mediated by the STAT4 N-domain. Mol Immunol. 2007; 44(8):1864-1872. [PubMed: 17095088]

75. Remmers EF, Plenge RM, Lee AT, et al. STAT4 and the risk of rheumatoid arthritis and systemic lupus erythematosus. N Engl J Med. 2007; 357(10):977-986. [PubMed: 17804842]

76. Lee HS, Remmers EF, Le JM, Kastner DL, Bae SC, Gregersen PK. Association of STAT4 with rheumatoid arthritis in the Korean population. Mol Med. 2007; 13(9-10):455-460. [PubMed: 17932559]

77. Kariuki SN, Kirou KA, MacDermott EJ, Barillas-Arias L, Crow MK, Niewold TB. Cutting edge: autoimmune disease risk variant of STAT4 confers increased sensitivity to IFN-alpha in lupus patients in vivo. J Immunol. 2009; 182(1):34-38. [PubMed: 19109131]

78. Gateva V, Sandling JK, Hom G, et al. A large-scale replication study identifies TNIP1, PRDM1, $J A Z F 1, U H R F 1 B P 1$ and $I L 10$ as risk loci for systemic lupus erythematosus. Nat Genet. 2009; 41(11):1228-1233. [PubMed: 19838195]

79. Han JW, Zheng HF, Cui Y, et al. Genome-wide association study in a Chinese Han population identifies nine new susceptibility loci for systemic lupus erythematosus. Nat Genet. 2009; 41(11): 1234-1237. [PubMed: 19838193]

80. Graham RR, Cotsapas C, Davies L, et al. Genetic variants near TNFAIP3 on 6q23 are associated with systemic lupus erythematosus. Nat Genet. 2008; 40(9):1059-1061. [PubMed: 19165918]

81. Taylor KE, Remmers EF, Lee AT, et al. Specificity of the STAT4 genetic association for severe disease manifestations of systemic lupus erythematosus. PLoS Genet. 2008; 4(5):e1000084. [PubMed: 18516230]

82. Palomino-Morales RJ, Rojas-Villarraga A, Gonzalez CI, Ramirez G, Anaya JM, Martin J. STAT4 but not TRAF 1/C5 variants influence the risk of developing rheumatoid arthritis and systemic lupus erythematosus in Colombians. Genes Immun. 2008; 9(4):379-382. [PubMed: 18432273]

83. Sigurdsson S, Nordmark G, Garnier S, et al. A risk haplotype of STAT4 for systemic lupus erythematosus is over-expressed, correlates with anti-dsDNA and shows additive effects with two risk alleles of IRF5. Hum Mol Genet. 2008; 17(18):2868-2876. [PubMed: 18579578]

84. Chung SA, Taylor KE, Graham RR, et al. Differential genetic associations for systemic lupus erythematosus based on anti-dsDNA autoantibody production. PLoS Genet. 2011; 7(3):e1001323. [PubMed: 21408207]

85. Zheng J, Yin J, Huang R, Petersen F, Yu X. Meta-analysis reveals an association of STAT4 polymorphisms with systemic autoimmune disorders and anti-dsDNA antibody. Hum Immunol. 2013; 74(8):986-992. [PubMed: 23628400]

86. Cohen S, Dadi H, Shaoul E, Sharfe N, Roifman CM. Cloning and characterization of a lymphoidspecific, inducible human protein tyrosine phosphatase, Lyp. Blood. 1999; 93(6):2013-2024. [PubMed: 10068674]

87. Vang T, Miletic AV, Bottini N, Mustelin T. Protein tyrosine phosphatase PTPN22 in human autoimmunity. Autoimmunity. 2007; 40(6):453-461. [PubMed: 17729039]

88. Rieck M, Arechiga A, Onengut-Gumuscu S, Greenbaum C, Concannon P, Buckner JH. Genetic variation in PTPN22 corresponds to altered function of T and B lymphocytes. J Immunol. 2007; 179(7):4704-4710. [PubMed: 17878369]

89. Lee YH, Rho YH, Choi SJ, et al. The PTPN22 C1858T functional polymorphism and autoimmune diseases - a meta-analysis. Rheumatology (Oxford). 2007; 46(1):49-56. [PubMed: 16760194]

90. Barrett JC, Hansoul S, Nicolae DL, et al. Genome-wide association defines more than 30 distinct susceptibility loci for Crohn's disease. Nat Genet. 2008; 40(8):955-962. [PubMed: 18587394] 
91. Yang W, Shen N, Ye DQ, et al. Genome-wide association study in Asian populations identifies variants in ETS1 and WDFY4 associated with systemic lupus erythematosus. PLoS Genet. 2010; 6(2):e1000841. [PubMed: 20169177]

92. Eliopoulos E, Zervou MI, Andreou A, et al. Association of the PTPN22 R620W polymorphism with increased risk for SLE in the genetically homogeneous population of Crete. Lupus. 2011; 20(5):501-506. [PubMed: 21543514]

93. Lea WW, Lee YH. The association between the PTPN22 C1858T polymorphism and systemic lupus erythematosus: a meta-analysis update. Lupus. 2011; 20(1):51-57. [PubMed: 21078766]

94. Bottini N, Musumeci L, Alonso A, et al. A functional variant of lymphoid tyrosine phosphatase is associated with Type I diabetes. Nat Genet. 2004; 36(4):337-338. [PubMed: 15004560]

95. Orru V, Tsai SJ, Rueda B, et al. A loss-of-function variant of PTPN22 is associated with reduced risk of systemic lupus erythematosus. Hum Mol Genet. 2009; 18(3):569-579. [PubMed: 18981062]

96. Menard L, Saadoun D, Isnardi I, et al. The PTPN22 allele encoding an R620W variant interferes with the removal of developing autoreactive B cells in humans. J Clin Invest. 2011; 121(9):36353644. [PubMed: 21804190]

97. Kariuki SN, Crow MK, Niewold TB. The PTPN22 C1858T polymorphism is associated with skewing of cytokine profiles toward high interferon-alpha activity and low tumor necrosis factor alpha levels in patients with lupus. Arthritis Rheum. 2008; 58(9):2818-2823. [PubMed: 18759295]

98. Weckerle CE, Mangale D, Franek BS, et al. Large-scale analysis of tumor necrosis factor alpha levels in systemic lupus erythematosus. Arthritis Rheum. 2012; 64(9):2947-2952. [PubMed: 22488302]

99. Katagiri Y, Mori K, Hara T, Tanaka K, Murakami M, Uede T. Functional analysis of the osteopontin molecule. Ann NY Acad Sci. 1995; 760:371-374. [PubMed: 7785920]

100. Forton AC, Petri MA, Goldman D, Sullivan KE. An osteopontin (SPP1) polymorphism is associated with systemic lupus erythematosus. Hum Mutat. 2002; 19(4):459. [PubMed: 11933203]

101. Scatena M, Liaw L, Giachelli CM. Osteopontin: a multifunctional molecule regulating chronic inflammation and vascular disease. Arterioscler Thromb Vasc Biol. 2007; 27(11):2302-2309. [PubMed: 17717292]

102. Cao W, Liu YJ. OPN: key regulator of pDC interferon production. Nat Immunol. 2006; 7(5):441443. [PubMed: 16622428]

103. Masutani K, Akahoshi M, Tsuruya K, et al. Predominance of Th1 immune response in diffuse proliferative lupus nephritis. Arthritis Rheum. 2001; 44(9):2097-2106. [PubMed: 11592372]

104. Chabas D, Baranzini SE, Mitchell D, et al. The influence of the proinflammatory cytokine, osteopontin, on autoimmune demyelinating disease. Science. 2001; 294(5547):1731-1735. [PubMed: 11721059]

105. Wong CK, Lit LC, Tam LS, Li EK, Lam CW. Elevation of plasma osteopontin concentration is correlated with disease activity in patients with systemic lupus erythematosus. Rheumatology (Oxford). 2005; 44(5):602-606. [PubMed: 15705633]

106. Rullo OJ, Woo JM, Parsa MF, et al. Plasma levels of osteopontin identify patients at risk for organ damage in systemic lupus erythematosus. Arthritis Res Ther. 2013; 15(1):R18. [PubMed: 23343383]

107. Han S, Guthridge JM, Harley IT, et al. Osteopontin and systemic lupus erythematosus association: a probable gene-gender interaction. PLoS ONE. 2008; 3(3):e0001757. [PubMed: 18335026]

108. D'Alfonso S, Barizzone N, Giordano M, et al. Two single-nucleotide polymorphisms in the $5^{\prime}$ and $3^{\prime}$ ends of the osteopontin gene contribute to susceptibility to systemic lupus erythematosus. Arthritis Rheum. 2005; 52(2):539-547. [PubMed: 15692970]

109. Kariuki SN, Moore JG, Kirou KA, Crow MK, Utset TO, Niewold TB. Age- and gender-specific modulation of serum osteopontin and interferon-alpha by osteopontin genotype in systemic lupus erythematosus. Genes Immun. 2009; 10(5):487-494. [PubMed: 19339987] 
110. Trivedi T, Franek BS, Green SL, et al. Osteopontin alleles are associated with clinical characteristics in systemic lupus erythematosus. J Biomed Biotechnol. 2011; 2011:802581. [PubMed: 22131818]

111. Wilkins C, Gale M Jr. Recognition of viruses by cytoplasmic sensors. Curr Opin Immunol. 2010; 22(1):41-47. [PubMed: 20061127]

112. Smyth DJ, Cooper JD, Bailey R, et al. A genome-wide association study of nonsynonymous SNPs identifies a Type 1 diabetes locus in the interferon-induced helicase (IFIH1) region. Nat Genet. 2006; 38(6):617-619. [PubMed: 16699517]

113. Sutherland A, Davies J, Owen CJ, et al. Genomic polymorphism at the interferon-induced helicase (IFIH1) locus contributes to Graves' disease susceptibility. J Clin Endocrinol Metab. 2007; 92(8):3338-3341. [PubMed: 17535987]

114. Strange A, Capon F, Spencer CC, et al. A genome-wide association study identifies new psoriasis susceptibility loci and an interaction between HLA-C and ERAP1. Nat Genet. 2010; 42(11):985990. [PubMed: 20953190]

115. Molineros JE, Maiti AK, Sun C, et al. Admixture mapping in lupus identifies multiple functional variants within $I F I H I$ associated with apoptosis, inflammation, and autoantibody production. PLoS Genet. 2013; 9(2):e1003222. [PubMed: 23441136]

116. Downes K, Pekalski M, Angus KL, et al. Reduced expression of $I F I H 1$ is protective for Type 1 diabetes. PLoS ONE. 2010; 5(9):e12646. [PubMed: 20844740]

117. Zouk H, Marchand L, Polychronakos C. Study of transcriptional effects in C is at the IFIH1 locus. PLoS ONE. 2010; 5(7):e11564. [PubMed: 20644636]

118. Nejentsev S, Walker N, Riches D, Egholm M, Todd JA. Rare variants of $I F I H 1$, a gene implicated in antiviral responses, protect against Type 1 diabetes. Science. 2009; 324(5925):387389. [PubMed: 19264985]

119. Robinson T, Kariuki SN, Franek BS, et al. Autoimmune disease risk variant of IFIH1 is associated with increased sensitivity to IFN-alpha and serologic autoimmunity in lupus patients. $\mathrm{J}$ Immunol. 2011; 187(3):1298-1303. [PubMed: 21705624]

120. Crampton SP, Deane JA, Feigenbaum L, Bolland S. Ifihl gene dose effect reveals MDA5mediated chronic type I IFN gene signature, viral resistance, and accelerated autoimmunity. $\mathrm{J}$ Immunol. 2012; 188(3):1451-1459. [PubMed: 22205024]

121. Ihle JN, Witthuhn BA, Quelle FW, Yamamoto K, Silvennoinen O. Signaling through the hematopoietic cytokine receptors. Annu Rev Immunol. 1995; 13:369-398. [PubMed: 7612228]

122. Decker T, Stockinger S, Karaghiosoff M, Muller M, Kovarik P. IFNs and STATs in innate immunity to microorganisms. J Clin Invest. 2002; 109(10):1271-1277. [PubMed: 12021240]

123. Hardy MP, Owczarek CM, Jermiin LS, Ejdeback M, Hertzog PJ. Characterization of the type I interferon locus and identification of novel genes. Genomics. 2004; 84(2):331-345. [PubMed: 15233997]

124. Richter MF, Dumenil G, Uze G, Fellous M, Pellegrini S. Specific contribution of Tyk2 JH regions to the binding and the expression of the interferon alpha/beta receptor component IFNAR1. J Biol Chem. 1998; 273(38):24723-24729. [PubMed: 9733772]

125. Schindler C, Plumlee C. Inteferons pen the JAK-STAT pathway. Semin Cell Dev Biol. 2008; 19(4):311-318. [PubMed: 18765289]

126. Cunninghame Graham DS, Akil M, Vyse TJ. Association of polymorphisms across the tyrosine kinase gene, TYK2 in UK SLE families. Rheumatology (Oxford). 2007; 46(6):927-930. [PubMed: 17384181]

127. Hellquist A, Jarvinen TM, Koskenmies S, et al. Evidence for genetic association and interaction between the TYK2 and IRF5 genes in systemic lupus erythematosus. J Rheumatol. 2009; 36(8): 1631-1638. [PubMed: 19567624]

128. Cunninghame Graham DS, Morris DL, Bhangale TR, et al. Association of NCF2, IKZF1, IRF8, IFIH1, and TYK2 with systemic lupus erythematosus. PLoS Genet. 2011; 7(10):e1002341. [PubMed: 22046141]

129. Lee YH, Choi SJ, Ji JD, Song GG. Associations between $P X K$ and $T Y K 2$ polymorphisms and systemic lupus erythematosus: a meta-analysis. Inflamm Res. 2012; 61(9):949-954. [PubMed: 22592861] 
130. Hom G, Graham RR, Modrek B, et al. Association of systemic lupus erythematosus with C8orf13-BLK and ITGAM-ITGAX. N Engl J Med. 2008; 358(9):900-909. [PubMed: 18204098]

131. Yang W, Tang H, Zhang Y, et al. Meta-analysis followed by replication identifies loci in or near $C D K N 1 B$, TET3, CD80, DRAM1, and ARID5B as associated with systemic lupus erythematosus in Asians. Am J Hum Genet. 2013; 92(1):41-51. [PubMed: 23273568]

132. Namjou B, Kothari PH, Kelly JA, et al. Evaluation of the TREX1 gene in a large multi-ancestral lupus cohort. Genes Immun. 2011; 12(4):270-279. [PubMed: 21270825]

133. Jacob CO, Zhu J, Armstrong DL, et al. Identification of IRAKI as a risk gene with critical role in the pathogenesis of systemic lupus erythematosus. Proc Natl Acad Sci USA. 2009; 106(15): 6256-6261. [PubMed: 19329491]

134. Kaufman KM, Zhao J, Kelly JA, et al. Fine mapping of Xq28: both MECP2 and IRAK1 contribute to risk for systemic lupus erythematosus in multiple ancestral groups. Ann Rheum Dis. 2013; 72(3):437-444. [PubMed: 22904263]

135. Liu JL, Zhang FY, Liang YH, et al. Association between the PD1.3A/G polymorphism of the $P D C D 1$ gene and systemic lupus erythematosus in European populations: a meta-analysis. J Eur Acad Dermatol Venereol. 2009; 23(4):425-432. [PubMed: 19220647]

136. Kozyrev SV, Abelson AK, Wojcik J, et al. Functional variants in the B-cell gene BANK1 are associated with systemic lupus erythematosus. Nat Genet. 2008; 40(2):211-216. [PubMed: 18204447]

137. Okada Y, Shimane K, Kochi Y, et al. A genome-wide association study identified $A F F 1$ as a susceptibility locus for systemic lupus eyrthematosus in Japanese. PLoS Genet. 2012; 8(1):e1002455. [PubMed: 22291604]

138. Li X, Ptacek TS, Brown EE, Edberg JC. Fcgamma receptors: structure, function and role as genetic risk factors in SLE. Genes Immun. 2009; 10(5):380-389. [PubMed: 19421223]

139. Sawalha AH, Webb R, Han S, et al. Common variants within MECP2 confer risk of systemic lupus erythematosus. PLoS ONE. 2008; 3(3):e1727. [PubMed: 18320046]

140. Webb R, Wren JD, Jeffries M, et al. Variants within $M E C P 2$, a key transcription regulator, are associated with increased susceptibility to lupus and differential gene expression in patients with systemic lupus erythematosus. Arthritis Rheum. 2009; 60(4):1076-1084. [PubMed: 19333917] 


\section{Executive summary}

- Many genetic risk factors for systemic lupus erythematosus (SLE) have been identified.

- Type I interferon (IFN) levels are high in SLE patients, and are a heritable risk factor for disease.

- A number of the genetic risk factors for SLE function within the type I IFN pathway.

- Studies of these genetic variations support the idea that they are gain-offunction, increasing the output of the type I IFN pathway.

- By mapping the genetics of the type I IFN pathway, we will greatly increase our understanding of SLE pathogenesis and improve diagnostic and therapeutic protocols. 


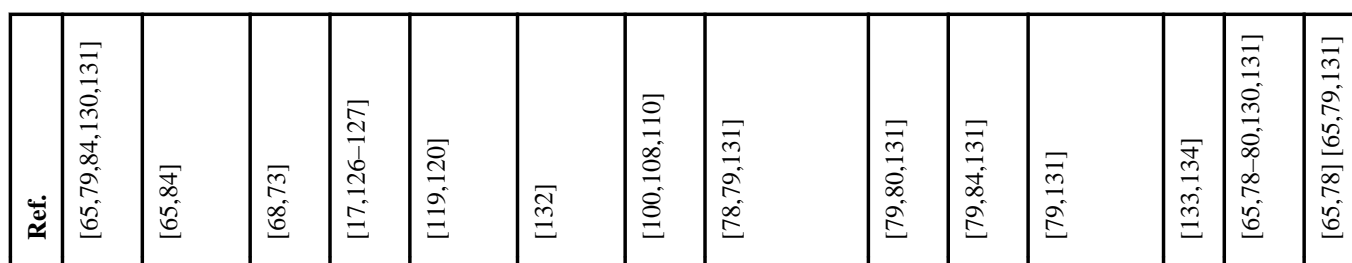
$<\leqslant$

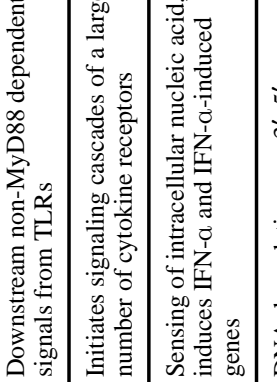

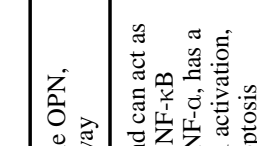

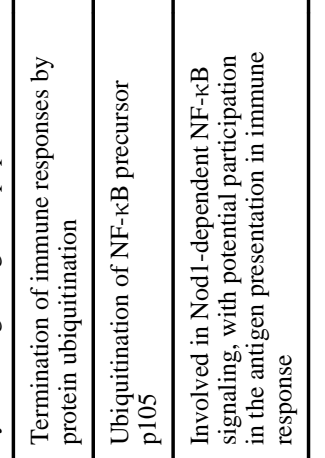

妾言詃

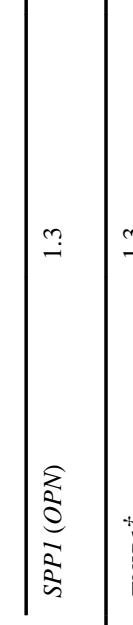

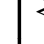

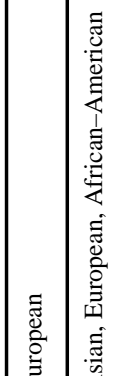

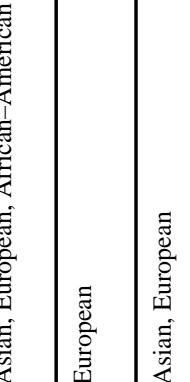

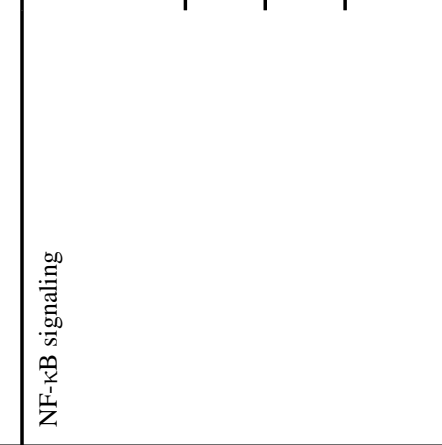

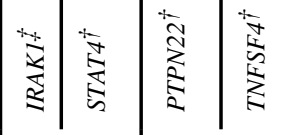




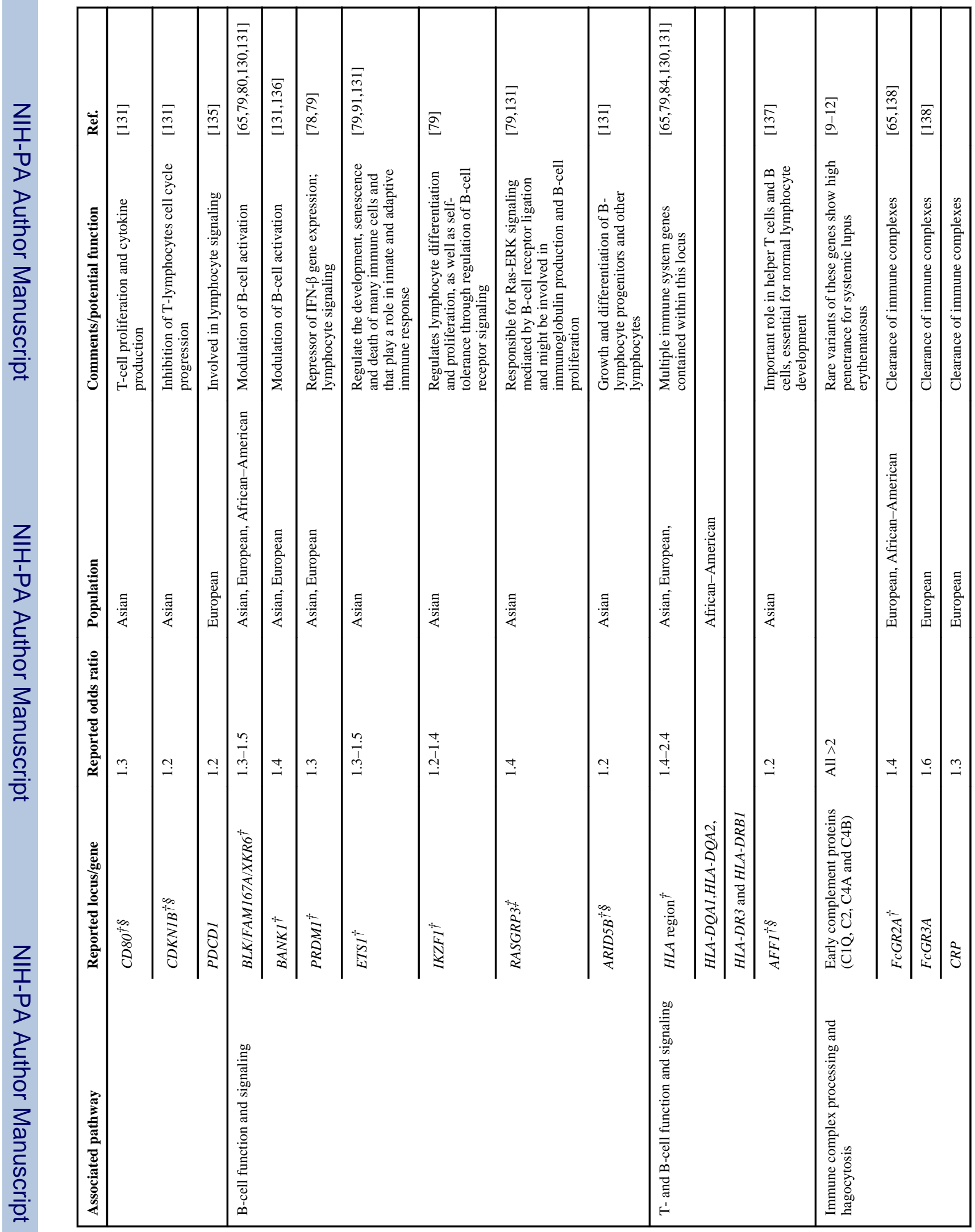




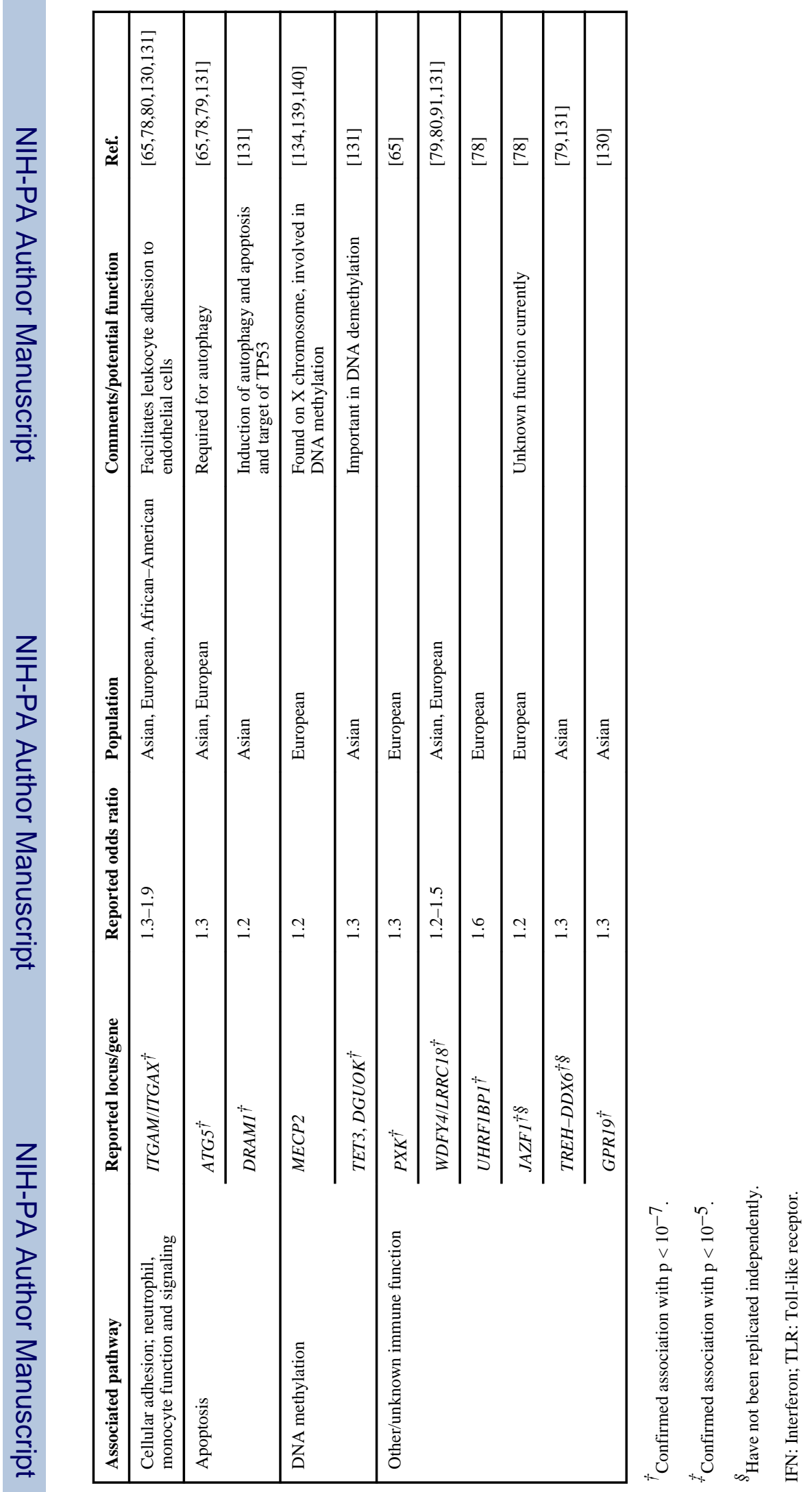

